Prof.dr hab.inz. Krzysztof Zboiński, mgr inz. Milena Golofit-Stawińska Politechnika Warszawska

\title{
Wstęp do analizy dynamiki pojazdu szynowego w krzywych przejściowych przy prędkościach większych od krytycznej
}

\begin{abstract}
Artykut przedstawia dyskusję autorów dotyczqca celowości podjęcia usystematyzowanego badania dynamiki ruchu pojazdów szynowych $w$ krzywych przejściowych przy prędkościach większych od krytycznej. Pomimo tego, że pojazdy szynowe budowane sq tak aby ich prędkość eksploatacyjna byta mniejsza od prędkości krytycznej (dla prędkości większych zachowanie modelu pojazdu reprezentowane jest przez rozwiazania stateczne okresowe), badania stateczności ruchu tak $w$ torze prostym jak $i$ tuku kołowym sq nieustannie prowadzone. Przyczyna sq nie tak rzadkie przypadki kiedy pojazd może poruszać się z prędkościq większq od krytycznej. Interesujacym dla autorów zagadnieniem sq własności dynamiczne układu na odcinkach toru umiejscowionych pomiędzy jest prosta i tukiem kołowym, tzn. w krzywych przejściowych. Trzeba tylko uzmystowić sobie kluczowa różnice formalnq $w$ tym przypadku. Jest niq tutaj ciagła zmiana promienia krzywizny i przechytki toru. W konsekwencji, nie można tu oczekiwać rozwiqzań statecznych stacjonarnych i statecznych okresowych, tak typowych dla analiz stateczności w torze prostym i tukach kołowych.
\end{abstract}

\section{Wstęp}

W artykule zawarto rozważania autorów na temat celowości podjęcia usystematyzowanych badań dynamiki pojazdów szynowych w krzywych przejściowych (KP) dla prędkości powyżej krytycznej $v_{n}$. Wiadomo, że pojazdy buduje się tak aby ich

prędkości eksploatacyjne były niższe od prędkości krytycznej, tzn. takiej powyżej której pojazd wężykuje, a zachowanie jego modelu reprezentują rozwiązania stateczne okresowe. Ponadto w tukach o mniejszych promieniach prędkości rzeczywistych 
obiektów mogą być dodatkowo niższe ze względu na występujące tam ograniczenia prędkości. Mimo to, ciągle prowadzi się intensywnie badania stateczności pojazdów szynowych w torze prostym i łukach kołowych. Powodem tych dociekań jest potrzeba dobrego poznania nieliniowych własności układów jakie stanowią pojazdy szynowe oraz to, że przypadki przekroczenia prędkości krytycznej przez pojazd mogą w rzeczywistości wystąpić. Przykładami takich sytuacji mogą być ruch pojazdu $\mathrm{Z}$ nadmierną prędkością, po awarii czy w złym stanie technicznym. Moga im odpowiadać uszkodzenia w układzie zawieszenia i nadmierne zużycie pary kołoszyna. Efektem jest obniżenie prędkości $v_{n}$, a w konsekwencji ruch wężykujący, pomimo pozostawania w nominalnie określonym zakresie prędkości eksploatacyjnych.

Podjęcie badań wymienionych zjawisk jest naturalne jeśli weźmiemy pod uwage dwa fakty. Pierwszy to bogata już wiedza dotycząca stateczności ruchu pojazdów szynowych w torze prostym i łukach kołowych, w tym wynikająca $\mathrm{z}$ badań jednego $\mathrm{z}$ autorów. Drugi to pośrednie cechy geometryczne krzywych przejściowych (KP), umiejscawiające je pomiędzy torem prostym (TP) i łukiem kołowym (ŁK). Poznanie własności dynamicznych takiego układu jest zagadnieniem niezmiernie ciekawym $\mathrm{z}$ badawczego punktu widzenia. Należy jednak uzmysłowić sobie zasadniczą formalną różnicę $\mathrm{w}$ tym przypadku. Otóż ciagła zmiana promienia krzywizny i przechyłki w krzywych przejściowych sprawia, że nie można tu oczekiwać rozwiązań statecznych, stacjonarnych i okresowych, typowych dla toru prostego i łuków kołowych. Rozwiązania ogólnie mówiąc mają w KP jednoznacznie przejściowych charakter.

Oprócz rozważań ogólnych w artykule przedstawiono: przegląd nielicznej literatury tematu; wyniki wcześniejszych badań symulacyjnych będących inspiracją i uzasadnieniem dla podjęcia badań; nieliczne nowe wyniki, w tym po raz pierwszy wyniki omawianego rodzaju dla (pasażerskiego) wagonu 4-osiowego; a także zakres badań przewidzianych przez autorów do wykonania w najbliższym czasie.

\subsection{Motywacja podjęcia tematu}

Problematykę należy uznać za bardzo rzadko podejmowaną w literaturze krajowej i zagranicznej. W przypadku pierwszego z autorów artykułu, mimo zainteresowania nią od pewnego czasu [1], [2], [3], [4], [5], ciagle pozostaje ona we wstępnym okresie badań. Oprócz cytowanych tu prac tego autora jako przykłady prac zawierających odpowiednie wyniki symulacji podać można [6] i inne nieliczne prace spółki autorskiej H. True i M. Hoffmann. We wszystkich wymienionych tu pracach wyniki symulacji ruchu w KP nie były bezpośrednim celem, a tym bardziej nie wynikały ze zorientowania bezpośrednio na problematykę podjętą $\mathrm{w}$ bieżącym artykule. Uzyskiwano je przypadkiem, podczas realizacji innych zadań. Autorzy artykułu nie znają żadnej pracy krajowej i zagranicznej, w której sednem jest dynamika pojazdu szynowego w krzywych przejściowych dla prędkości powyżej $v_{n}$.

Zagadnienie bez wątpienia ma na obecnym etapie wymiar teoretyczny. Niektórzy pewnie stwierdzą, że jest ono aż nazbyt teoretyczne i nie widać dla niego zastosowań praktycznych. Autorów to nie niepokoi. Pierwszy z autorów wielokrotnie spotykał się z podobnymi opiniami w początkowym okresie różnych badań przez niego prowadzonych. Było tak na przykład z dokładnym modelowaniem sił pozornych. Autor pamięta wiele sceptycyzmu, a nawet uśmiechów kiedy prezentował takie podejście. Dziś jednak przestało to dziwić, a wiele z komercyjnych pakietów i programów indywidualnych opisujących dynamikę pojazdów szynowych robi to dokładnie (bez żadnych uproszczeń). Ta zmiana poglądów jest w jakimś stopniu także efektem działalności tego autora [3], [7] i [8]. Zupełnie podobna sytuacja dotyczy badań stateczności pojazdów szynowych w łuku kołowym. $\mathrm{Na}$ początku mało kto się tym problemem zajmował. Istniało jednoznacznie przekonanie ze zagadnienie nie ma praktycznego wymiaru. Autor musiał niejednokrotnie polemizować z takimi opiniami [2], [9], [10]. Dziś grupa badaczy, która podjęła problem jest duża. Liczba publikacji idzie już w dziesiątki i co roku przyrasta. Co więcej, dostrzeżono aspekty praktyczne tych badań. Przykładem może być aktualnie badane zagadnienie wpływu szerokości toru na stateczność w ŁK. Prowadzone jest ono w m.in. kontekście możliwości wprowadzenia do praktyki symulacyjnych badań dopuszczeniowych (homologacyjnych) oraz określenia w jakich warunkach (dla jakiego luzu koło-szyna) badań dotyczących stateczności w łuku można by zaniechać [11]. Kolejnym podobnym przykładem jest problematyka kształtowania krzywych przejściowych w oparciu o kompletne modele pojazdów. Niegdyś, a także w podejściu inżynierskim współcześnie, wielu autorów stosuje punkt materialny aby odwzorować pojazd. Dziś jednak liczba prac badawczych traktujących zagadnienie dynamicznie, z uwzględnieniem kompletnych modeli pojazdów, tak jak robi pierwszy z autorów artykułu od lat [12], [3], [13] i [14], jest bardzo duża. Mimo, że w praktyce stosowana jest parabola 3-go stopnia (ew. klotoida), to liczba prac gdzie podejmowane sa badania nad innymi kształtami (wielomianowe i parametryczne KP) jest współcześnie bardzo duża. Niektóre wyniki badań naukowych podważają utarte poglądy w sposób jednoznaczny i tak różny od standardów, że aż trudny dla niektórych do akceptacji. Przykładem tego rodzaju jest [5], gdzie wbrew tradycyjnemu podejściu w celu poprawy własności dyna- 
micznych W KP zaproponowano inną funkcję opisująca krzywiznę $i$ inną opisującą rampę przechyłkową.

Autorzy artykułu są przekonani, że podobnie będzie i z poruszanym tu zagadnieniem. Jak tylko wiedza na jego temat wzrośnie, to nie minie wiele czasu jak zacznie ona być wykorzystywana i stanie się dobrem powszechnym. Alternatywą jest tu bierność własna, której skutkiem może być tylko to, że inni badacze problem podejmą, rozwiążą i zdobędą uznanie, choć tak samo mogą nie mieć na początku dojrzałej wizji jak otrzymane wyniki praktycznie wykorzystać. Zdaniem autorów badania dynamiki pojazdów szynowych w KP powyżej prędkości krytycznej, zarówno w ujęciu ogólnym jak i dla indywidualnych pojazdów, mogą być bardzo przydatne $\mathrm{w}$ poszukiwaniu rozwiązania problemu budowy pojazdów o własnościach równie dobrych w TP jak i w ciasnych $Ł K$. Wiadomo bowiem od lat, że obie własności są przeciwstawne i trudne do pogodzenia. Osiagnnięcie wysokich prędkości krytycznych $\mathrm{z}$ jednoczesnym dobrym prowadzeniem $\mathrm{w}$ łuku i odwrotnie jest ciagle otwartym wyzwaniem dla współczesnej dynamiki pojazdów szynowych. Wyrazem zainteresowania na świecie tematyką poruszaną $\mathrm{w}$ podrozdziale niech będzie ostatnio opublikowany rozdział autora w opracowaniu monograficznym [5]. Dotychczasowe badania autorów $\mathrm{w}$ omawianym zakresie służyły głównie celom poznawczym. Wyniki tych badań przedstawiono poniżej.

\section{Obiekty dla których dla których wykonano badania $i$ ich modele}

Zasadniczo wyniki prezentowane dalej dotyczą dwóch grup obiektów. Pierwsza, związana jest wynikami uzyskanymi wcześniej, i dotyczy obiektów 2osiowych. Są to towarowe wagony 2-osiowe i wózki 2 -osiowe wagonów. Grupa druga, związana jest $\mathrm{z}$ najnowszymi wynikami, i dotyczy 4-osiowego (wózkowego) wagonu pasażerskiego MK111. Wszystkie modele pojazdów i wózków uzupełnione są dyskretnymi modelami toru, poprzecznie i pionowo podatnego. Struktura modeli 2-osiowych, poza wózkiem $25 \mathrm{TN}$, jest taka sama i przedstawiona na rys. 1a. Różnice dla wózka 25TN omówiono np. w [3]. Struktura wagonu MK111 (o brytyjskim rodowodzie) przedstawiona jest na rys. 2. Modele toru przedstawiono na rys. $1 \mathrm{~b}$ i 1c. Dla modeli obiektów i toru założono liniowe charakterystyki elementów sprężystych i thumiących. Większość symulacji otrzymano dla par profili koło-szyna S1002-UIC60, a nieliczne dla pary BR P10-UIC60. Zasady budowy modeli matematycznych dla wymienionych układów pojazdtor zgodne są z opisanymi w [3] i [8]. W pracy [3] omówiono też zastosowany sposób modelowania kontaktu koło-szyna. Uwzględnia on zarówno nieliniową geometrie profili koła i szyny jak i nieliniowe wyznaczanie sił kontaktowych stycznych w oparciu o procedurę FASTSIM, np. [16]. Modele układu wagon (wózek) 2-osiowy-tor mają 18 stopni swobody. Model wózek 25TN-tor posiada 16 stopni a)
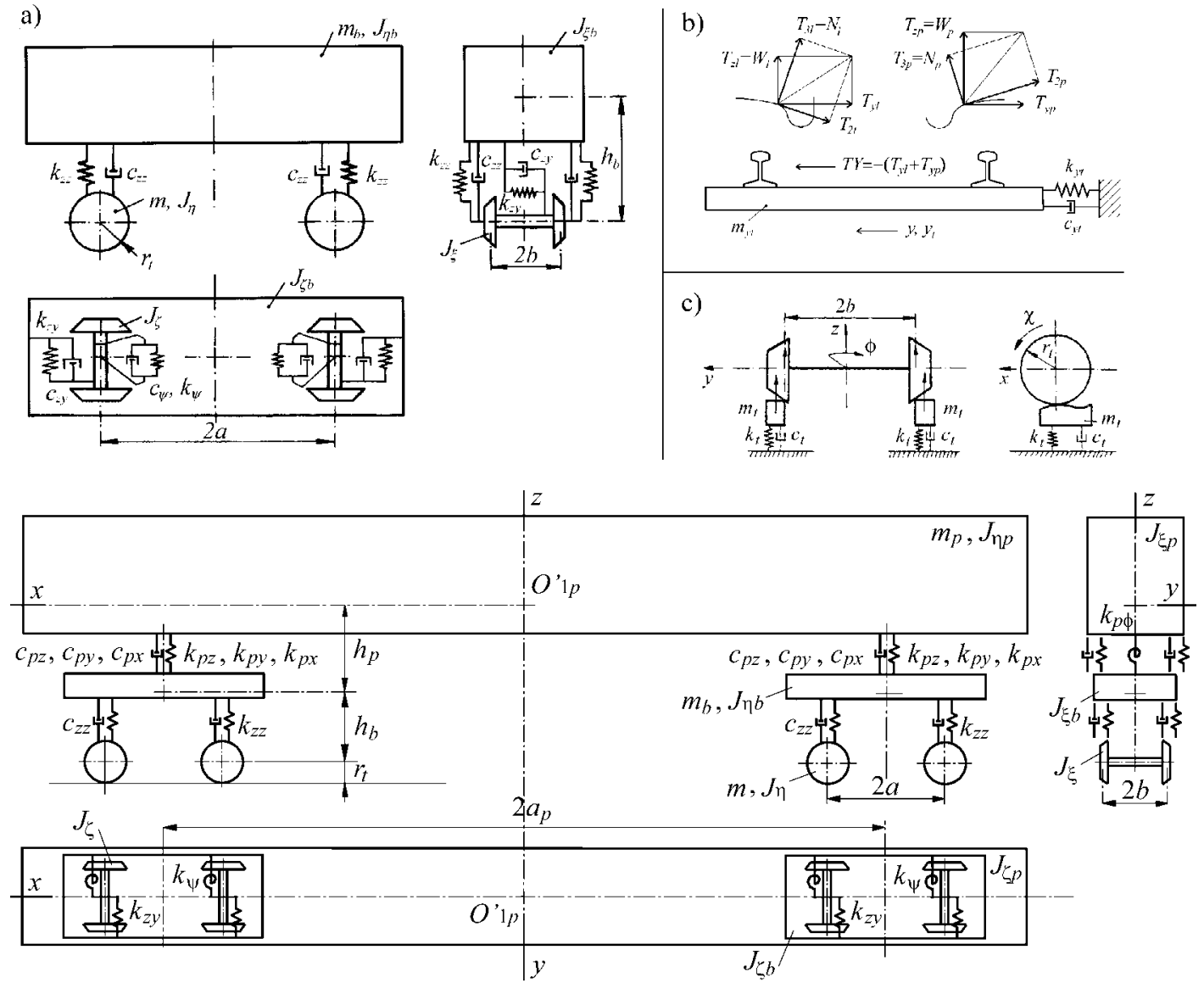

Rys. 1. Struktura modeli nominalnych: a) pojazdu (wózka) 2-osio-wego, b) toru po-datnego poprzecznie, c) toru podatnego pionowo

Rys. 2. Struktura modelu nominalnego 4osiowego wagonu pasażerskiego MK111 
swobody. Model wagon MK111-tor posiada 38 stopni swobody. Ten ostatni model wygenerowany został programem ULYSSES do automatycznej generacji równań ruchu, np. [17]. Parametry modeli obiektów i toru podano m.in. w [3]. Część parametrów wagonu MK111 uzyskano w British Rail Research, Derby.

\section{Wyniki badań}

3.1. Wyniki badań wcześniejszych, tj. dla obiektów 2-osiowych

Ilustrację graficzną wyników musimy tu ograniczyć ze względu na wymagania redakcyjne. Przedstawiony jednak zostanie pełny zakres wniosków wyciagniętych na podstawie badań dla obiektów 2-osiowych. Czytelnikom zainteresowanym wiekszą liczbą przykładów symulacji polecić można przede wszystkim prace [2], [3], [5]. Wyniki przedstawiono na rys. 3-7. Wykresy na tych rysunkach przedstawiają głównie przebiegi współrzędnych dynamiki poprzecznej pojazdu w funkcji drogi. Sporadycznie na wykresach przedstawiane są też współrzędne dynamiki pionowej. Mówiąc ściśle, wykresy przedstawiają przemieszczenia poprzeczne $y$ i pionowe $z$ oraz katy kołysania $\phi$ i obracania $\psi$. Indeksy $b, p$ oraz $k$ oznaczają odpowiednio nadwozie wagonu o osiach swobodnych lub ramę wózka, przedni zestaw kołowy oraz końcowy zestaw kołowy.

Trasy, po których porusza się pojazd składają się zawsze z TP, KP i ŁK. Użyta krzywa przejściowa jest zawsze paraboliczna 3-go stopnia. Dokładne parametry tras podano $\mathrm{w}$ podpisach pod rysunkami. Ruch pojazdu odbywa się zawsze ze stałą prędkością $v$. W niektórych przypadkach zastosowane prędkości $v$ wydawać się mogą duże, zwłaszcza dla ruchu po łuku. Mogłoby to skutkować możliwością wykolejenia rzeczywistego pojazdu. Z drugiej strony, jak już wspominano pojazdy buduje się $\mathrm{w}$ taki sposób aby prędkość krytyczna $v_{n}$ leżała powyżej ich prędkości eksploatacyjnych. Tu największa wartość $v$ zastosowana została do wózka MK111 wagonu pasażerskiego, który ze swej natury może poruszać się z prędkościami większymi niż badane tu wagony towarowe 2-osiowe. Bez względu na relację pomiędzy prędkościami eksploatacyjnymi poszczególnych obiektów i prędkościami użytymi w badaniach wszystkie przypadki, nawet mało realistyczne, uznać można za interesujące $\mathrm{z}$ badawczego punktu widzenia.

Wybrane do prezentacji wyniki dotyczą 2-osiowego wagonu towarowego hsfvl o brytyjskim pochodzeniu, wirtualnego wagonu towarowego 2osiowego (nazwa przyjęta w badaniach), wózka 25TN wagonu towarowego i wózka MK111 wagonu pasażerskiego. Na podstawie uzyskanych wyników, $\mathrm{w}$ tym przedstawionych $\mathrm{w}$ artykule, $\mathrm{w}$ przypadku przejazdu pojazdu z TP w ŁK przez KP kiedy w TP i w ŁK występuje cykl graniczny, można wyróżnić trzy główne rodzaje zachowania w KP. Po pierwsze, drgania w KP są logiczną kontynuacją (płynnym przejściem) pomiędzy drganiami w TP i ŁK (rys. 3 i 4). Mogą one przy tym mieć zarówno malejący (rys. 3) jak i rosnący (rys. 4) charakter. Zależy to od relacji wzajemnej amplitud dla TP i ŁK oraz asymetrii cyklu granicznego $\mathrm{w} Ł K$, a także od parametrów zawieszenia pojazdu. Po drugie, zachowanie w KP może mieć postać nie wynikająca w sposób logiczny z postaci (drgań) w TP i ŁK. Przy czym drgania mogą narastać $\mathrm{w}$ ten sposób, że osiaggają amplitudy większe od tych dla TP (rys. 4) i ŁK. Mogą też całkowicie zanikać w KP, przy czym może się to odbywać w sposób stopniowy (rys. 6), jak również zupełnie nagły (rys. 5). Po trzecie, możliwa jest bifurkacja rozwiązań w KP, od jednego do innego typu rozwiązań. Może ona polegać na nagłym przeskoku (rys. 7) lub dość płynnym przejściu (rys. 6) do innego rozwiązania. $\mathrm{Na}$ pierwszym z wymienionych rysunków obserwujemy przeskok od jednej postaci drgań samowzbudnych do innej (nagła zmiana amplitudy i częstości drgań), a na drugim płynne przejście od drgań do rozwiązania stacjonarnego (quasi-stacjonarnego).

Uzyskaną metodami symulacyjnymi różnorodność zachowań układu pojazd-tor podczas ruchu pojazdu po KP z prędkością powyżej krytycznej $v_{n}$ można uznać za bardzo dużą. Różnorodność ta i brak przewidywalności zachowania w KP w sposób jednoznaczny ukazują silnie nieliniowe własności układu. Zważmy, że nawet jeśli dla danego obiektu znamy obszary stateczności w TP i w pełnym zakresie promieni $R \mathrm{w} Ł \mathrm{~K}$, to trudno na tej podstawie

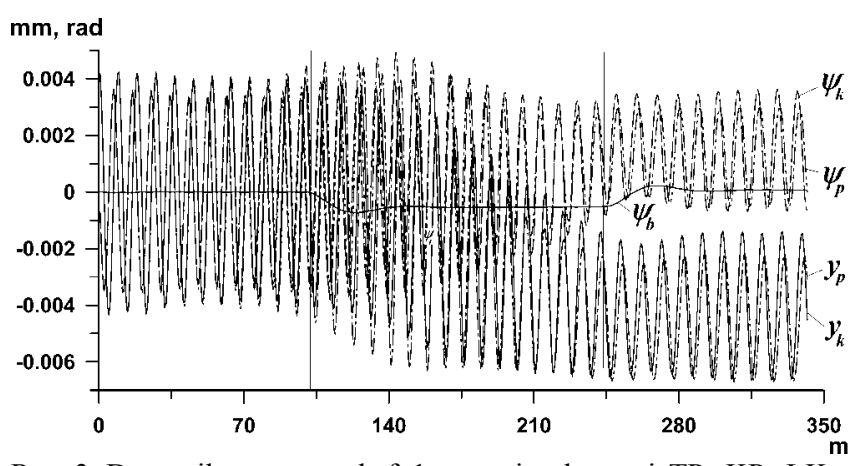

Rys. 3. Dynamika wagonu hsfvlna trasie złożonej TP, KP, ŁK: $v=45,3 \mathrm{~m} / \mathrm{s} ; \mathrm{KP}\left(R_{\min }=600 \mathrm{~m}, H_{\max }=0,16 \mathrm{~m}, L=142 \mathrm{~m}\right)$; obniżona w stosunku do nominalnej sztywność wzdłużna zawieszenia

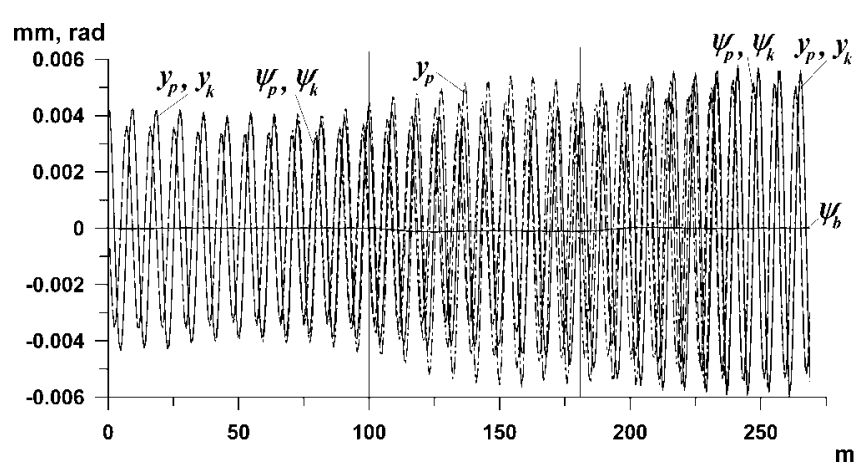


Rys. 4. Dynamika wagonu hsfvlna trasie złożonej TP, KP, ŁK: $v=45,3 \mathrm{~m} / \mathrm{s} ; \operatorname{KP}\left(R_{\min }=6000 \mathrm{~m}, H_{\max }=0,051 \mathrm{~m}, L=82,6 \mathrm{~m}\right)$; obniżona w stosunku do nominalnej sztywność wzdłużna zawieszenia

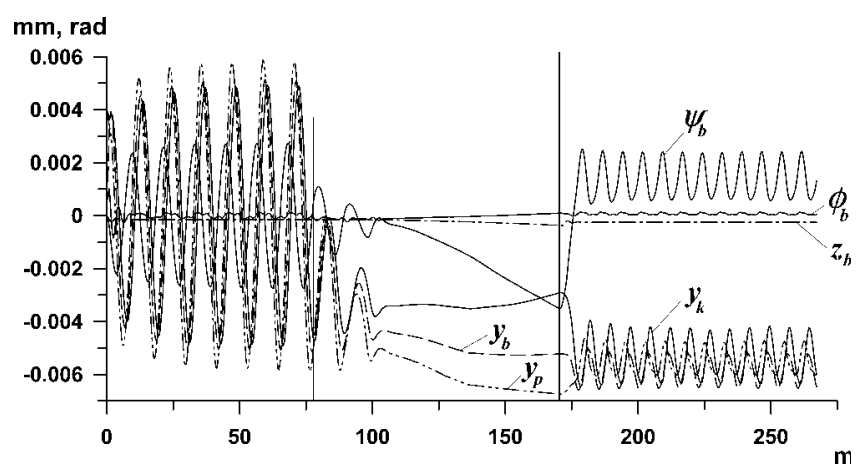

Rys. 5. Dynamika wózka $25 \mathrm{TN}$ wagonu towarowego na trasie złożonej TP, KP, ŁK: $v=29,5 \mathrm{~m} / \mathrm{s} ; \mathrm{KP}\left(R_{\min }=300 \mathrm{~m}, H_{\max }=0,15 \mathrm{~m}\right.$, $L=89,7 \mathrm{~m})$; obniżona $\mathrm{w}$ stosunku do nominalnej sztywność poprzeczna zawieszenia

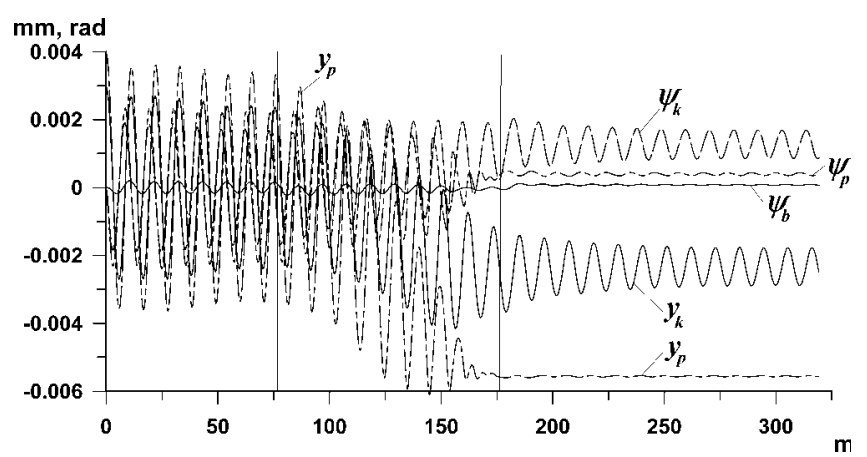

Rys. 6. Dynamika wagonu 2-osiowego na trasie złożonej TP, KP, ŁK: $v=41 \mathrm{~m} / \mathrm{s} ; \mathrm{KP}\left(R_{\min }=600 \mathrm{~m}, H_{\max }=0,128 \mathrm{~m}, L=102,4 \mathrm{~m}\right)$

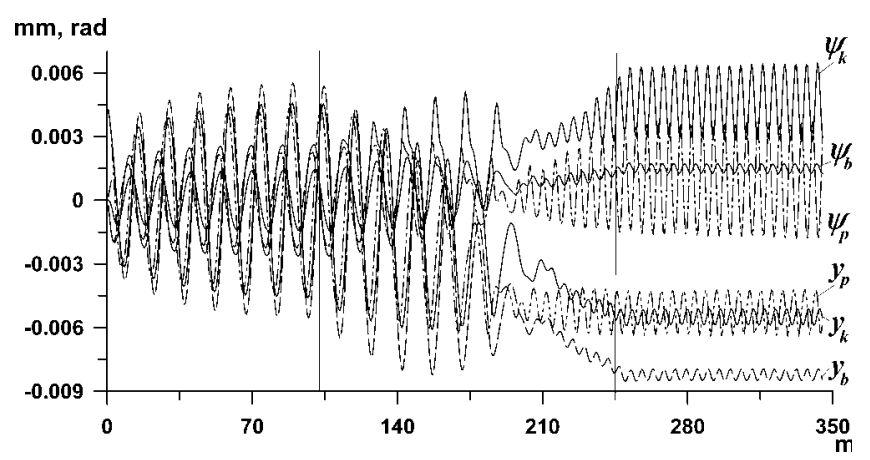

Rys. 7. Dynamika wózka MK111 wagonu pasażerskiego na trasie złożonej TP, KP, ŁK: $v=54 \mathrm{~m} / \mathrm{s} ; \mathrm{KP}\left(R_{\min }=600 \mathrm{~m}, H_{\max }=0,15 \mathrm{~m}\right.$, $L=89,7 \mathrm{~m})$; obniżona w stosunku do nominalnej sztywność poprzeczna zawieszenia, podniesione tłumienie poprzeczne zawieszenia oraz zwiększona sztywność i tłumienie toru

przewidzieć jak zachowa się pojazd w KP przy prędkościach większych od $v_{n}$. Jest tak mimo, iż KP jest obiektem bez wątpienia umiejscowionym w sensie geometrii pomiędzy TP i ŁK. Na podstawie dotychczasowych wyników można stwierdzić, że na zachowanie układu w omawianych warunkach ma wpływ wiele czynników. W sposób jednoznaczny wyniki wskazują na przechyłkę $H$, promień łuku $R$ i na model pojazdu (np. więzy i wartości parametrów) jako na czynniki prowadzące do jakościowych (i oczywiście ilościowych) różnic zachowania modelu pojazdu w KP. Jak wspominano omówione wyniki otrzymano podczas badań o zupełnie innych celach, dlatego ich liczba nie jest duża. Stąd autorzy nie czują się uprawnieni do głębszego wnioskowania.

3.2. Najnowsze wyniki badań, tj. dla wagonu 4-osiowego

Wynki prezentowane ponizej są tak ważne jak i ciekawe. Wynika to $\mathrm{z}$ tego, że dla pojazdów wózkowych zjawisko wężykowania jest bardziej złożone i jednocześnie rzadziej obserwowane, tak w rzeczywistości jak i w badaniach. $Z$ reguły pojazdy tego rodzaju posiadają wyraźnie większą prędkość krytyczną od pojazdów 2-osiowych. Przykładem pracy, w której analizowano prędkość krytyczną pojazdu 4osiowego w TP jest [18].

Jak dla pojazdów 2-osiowych tak i tu ilustrację graficzną wyników musimy ograniczyć. Wnioski obejmą jednak wszystkie wyniki uzyskane dla badanego wagonu 4-osiowego MK111. Wyniki przedstawiono na rys. 8-15. Dotyczą one ruchu po trasie złożonej z TP, KP i ŁK. Krzywa prajściowa jest parabolą 3 stopnia. Parametry tras to: $\mathrm{TP}(L=50 / 150 \mathrm{~m}), \quad \mathrm{KP}\left(R_{\min }=600 \mathrm{~m}, H_{\max }=0,15 \mathrm{~m}\right.$, $L=180,46 \mathrm{~m}), \mathrm{LK}(R=600 \mathrm{~m}, H=0,15 \mathrm{~m}, L=100 \mathrm{~m})$. Ruch pojazdu odbywa się ze stałą prędkością $v$, krórą wariantowano a wartości podano $\mathrm{w}$ podpisach pod rysunkami. Wariantowaniu podlegały też warunki początkowe. Na rys. 8-11 były one zerowe, a na rys. 12-15 na wszystkie 7 brył modelu nałożono początkowe przemieszczenie poprzeczne $y_{1}(0)=y_{2}(0)=y_{3}(0)=y_{4}(0)=y_{b 1}(0)=y_{b 2}(0)=y_{p}(0)=0,004 \mathrm{~m}$ . Kolejno użyte symbole odnoszą się do zestawów kołowych (od tyłu ku przodowi), ram wózków (od tyłu ku przodowi) i nadwozia. Dla zerowych warunków długość $L \quad$ w TP wynosiła $50 \mathrm{~m}$, dla niezerowych $150 \mathrm{~m}$.

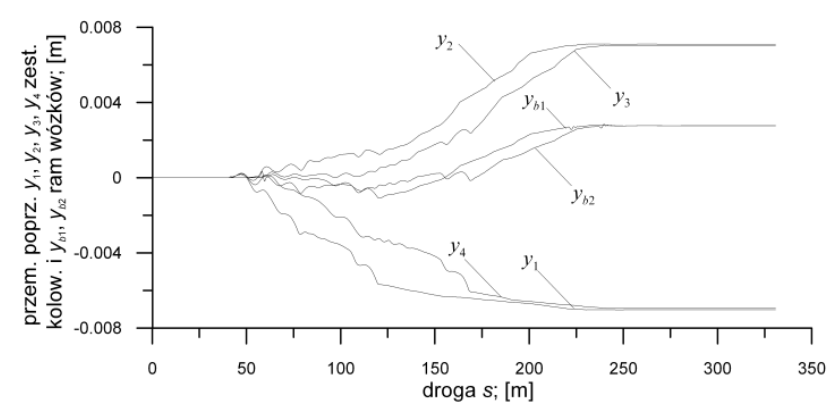

Rys. 8. Dynamika wagonu 4-osiowego MK111 na trasie TP, KP, ŁK: $v=15 \mathrm{~m} / \mathrm{s}$; zerowe warunki początkowe

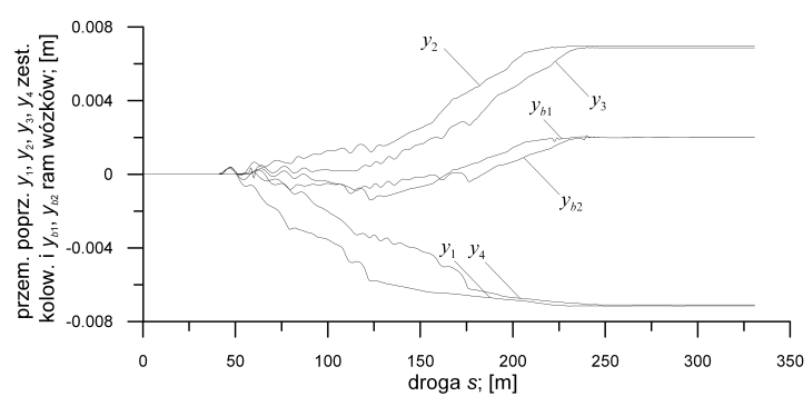

Rys. 9. Dynamika wagonu 4-osiowego MK111 na trasie TP, KP, ŁK: $v=20 \mathrm{~m} / \mathrm{s}$; zerowe warunki początkowe 


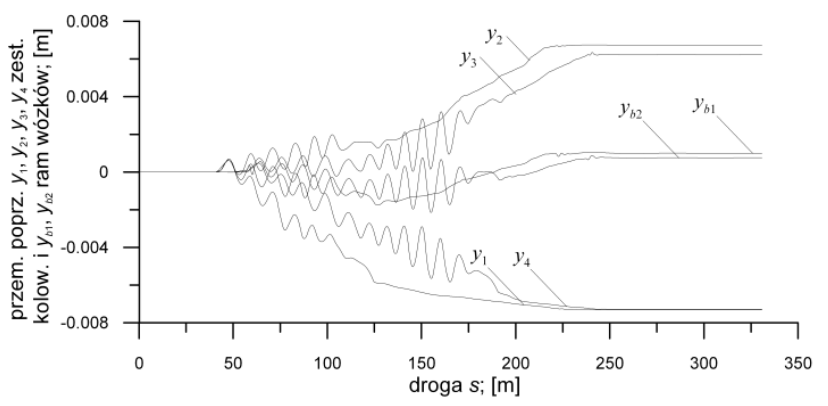

Rys. 10. Dynamika wagonu 4-osiowego MK111 na trasie TP, $\mathrm{KP}, \mathrm{ŁK}: v=25 \mathrm{~m} / \mathrm{s}$; zerowe warunki początkowe

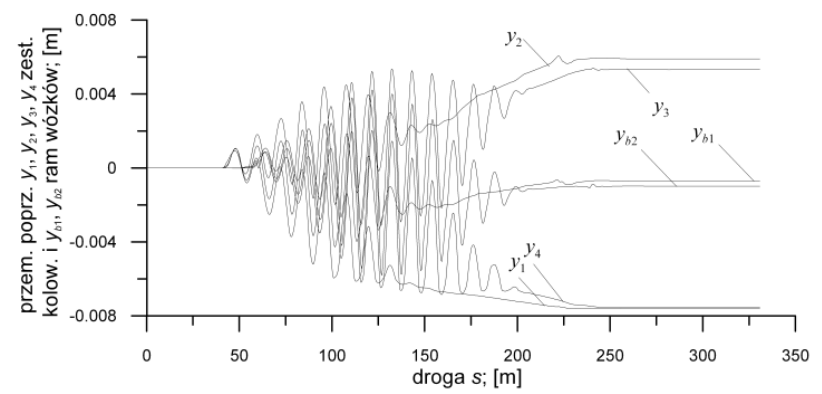

Rys. 11. Dynamika wagonu 4-osiowego MK111 na trasie TP, $\mathrm{KP}, \mathrm{ŁK}: v=30,78 \mathrm{~m} / \mathrm{s}$; zerowe warunki początkowe

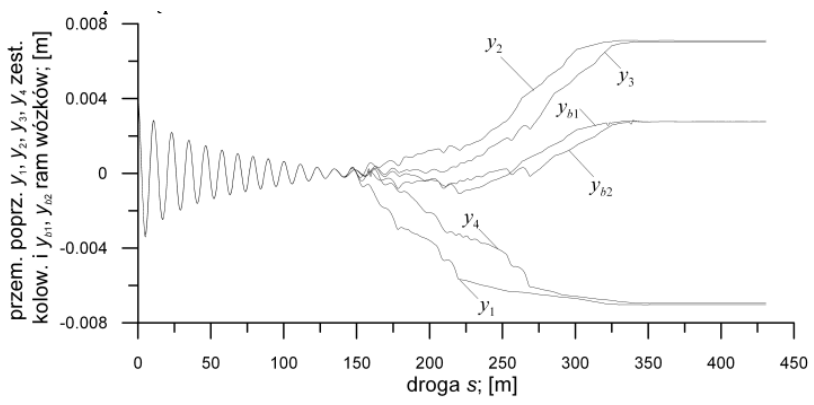

Rys. 12. Dynamika wagonu 4-osiowego MK111 na trasie TP, $\mathrm{KP}, \mathrm{ŁK}: v=15 \mathrm{~m} / \mathrm{s}$; niezerowe warunki początkowe

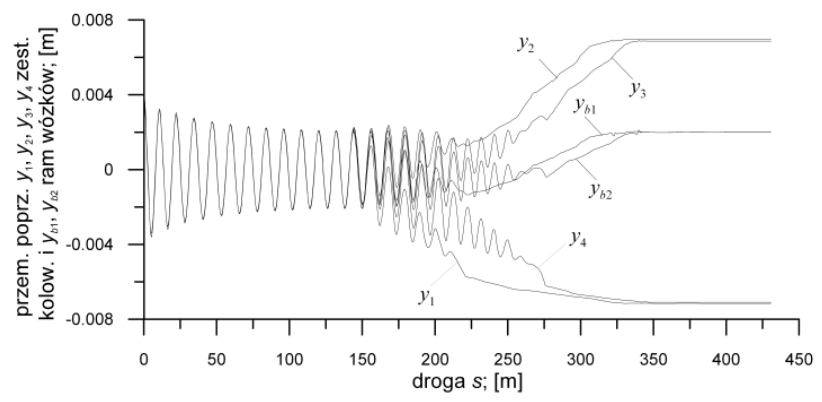

Rys. 13. Dynamika wagonu 4-osiowego MK111 na trasie TP, $\mathrm{KP}, \mathrm{KK}: v=20 \mathrm{~m} / \mathrm{s}$; niezerowe warunki początkowe

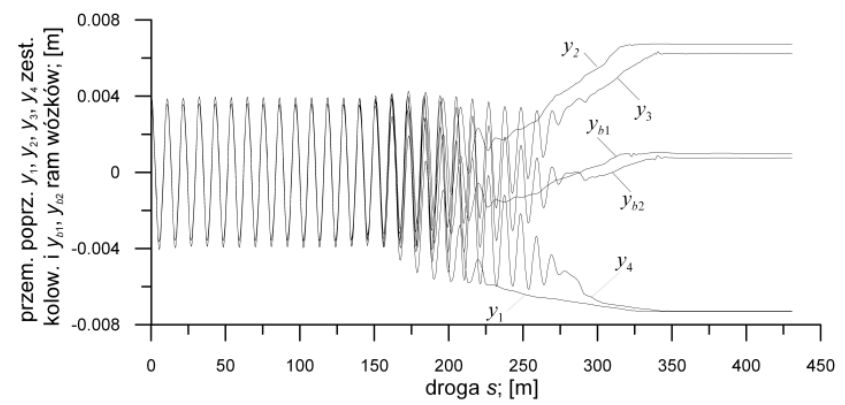

Rys. 14. Dynamika wagonu 4-osiowego MK111 na trasie TP, $\mathrm{KP}, \mathrm{ŁK}$ : $v=25 \mathrm{~m} / \mathrm{s}$; niezerowe warunki początkowe

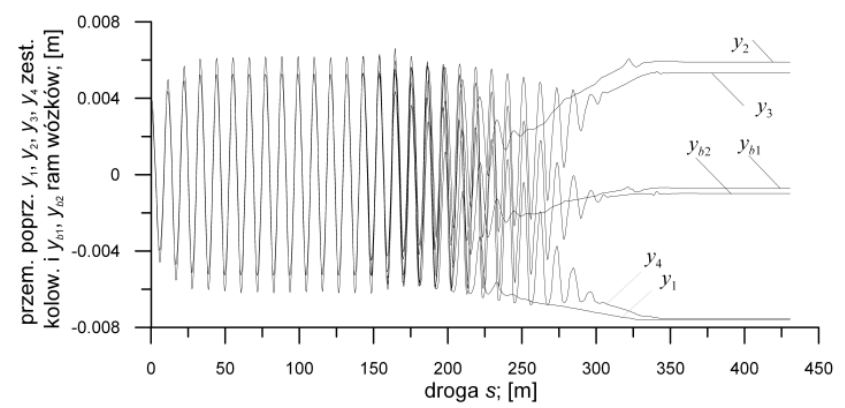

Rys. 15. Dynamika wagonu 4-osiowego MK111 na trasie TP, $\mathrm{KP}, Ł K: v=30,78 \mathrm{~m} / \mathrm{s}$; niezerowe warunki początkowe

Analiza rys. 12 i 13 pokazuje, że prędkość krytyczna $v_{n}$ pojazdu w TP leży pomiędzy 15 , a 20 $\mathrm{m} / \mathrm{s}$ (w pobliżu $20 \mathrm{~m} / \mathrm{s}$ ). Dla żadnej z prędkości (badano także $v=35 \mathrm{~m} / \mathrm{s}$ ) i obu typów warunków początkowych nie uzyskano cyklu granicznego w ŁK. Odnotujmy jednak, że promień łuku $R=600 \mathrm{~m}$ jest względnie mały. Porównując wyniki przy zerowych i niezerowych warunkach początkowych widać, że sposób wymuszenia drgań (wjazd w łuk lub niezerowe warunki) ma wpływ na obraz zachowania obiektu w KP. Widać to najlepiej porównując parę rys. 9 i $10 \mathrm{z}$ parą rys. 13 i 14 , które dotyczą tych samych prędkości. Na rys. 13 mamy wyraźne drgania w KP, podczas gdy na rys. 9 prawie ich nie widać. Analizując rysunki z niezerowymi warunkami, co odpowiada warunkom ruchu dla obiektów 2-osiowych, widać że rodzaj zachowania wagonu 4-osiowego w KP jest nablizszy temu $\mathrm{z}$ rys. 6.

\section{Cele i zakres najbliższych badań - wnioski}

$\mathrm{Na}$ podstawie przedstawionych wyników można sformułować cele najbliższych badań. Byłoby to poznanie możliwie największej liczby rodzajów zachowań w KP dla ruchu powyżej prędkości krytycznej $v_{n}$. Kolejne byłoby sklasyfikowanie tych rodzajów w sensie postaci. Następne w kolejności, to wyjaśnienie przyczyn (okoliczności) występowania lub nie występowania tych postaci. Wyjaśnienie (zbadanie) na ile moment wjazdu w KP (pojawienia się KP) po odcinku poprzedzającym (TP lub ŁK) może mieć wpływ na zachowanie w KP. Zauważmy, że ruch powyżej prędkości $v_{n}$ po odcinku poprzedzającym stanowi warunki początkowe dla wzbudzenia drgań w KP. Stąd różne momenty wjazdu w KP (odpowiadające innej aktualnej wartości przemieszczeń na odcinku poprzedzającym) stanowią odmienne warunki początkowe, być może mogące skutkować różnym zachowaniem układu.

Wymienione wyżej cele byłyby osiagnięte $\mathrm{z}$ wykorzystaniem symulacji. Tak postawione zadanie to symulacyjne badanie nieliniowej dynamiki pojazdu szynowego w KP. Formalnie, jest ono różne od 
badania stateczności [9] i [10], opartego na poszukiwaniu rozwiązań statecznych stacjonarnych lub statecznych okresowych. W omawianym tu zagadnieniu zjawiska mają bowiem przejściowy charakter. Mimo to, związek pomiędzy obu wymienionymi zadaniami jest niepodważalny. Powoduje to, że można w pewnym stopniu przenieść korzyści wynikające $\mathrm{z}$ badań stateczności w łuku na planowane przyszłe badania. Stąd uzasadnieniem dla rozwijania omawianej tematyki mogą być elementy eksponujące związek stateczności $\mathrm{z}$ bezpieczeństwem. W szczególności mamy na myśli wyższe prędkości krytyczne oraz dążenie do lepszego powiązania prędkości fizycznego wykolejenia pojazdu z tzw. wykolejeniem numerycznym, oznaczającym zatrzymanie obliczeń symulacyjnych. W uzupełnieniu można wyeksponować pewne ważne korzyści, jakie zostaną uzyskane zakładając, że cele sformułowane wyżej da się osiąnaç. Otóż informacją o takim ważnym, wręcz fundamentalnym, znaczeniu byłoby wyjaśnienie, w jakich okolicznościach amplitudy drgań w KP są większe niż w TP i $Ł K$ oraz $w$ jakich drgania w KP zanikają całkowicie, mimo ruchu z prędkością większą od $v_{n}$. Jest oczywiste, że poznanie i zrozumienie przyczyn i okoliczności tak diametralnie różnych zachowań może potencjalnie zaowocować podjęciem działań (do działań projektowych włącznie) zmierzających do eliminacji pierwszego ze zjawisk (stan bardzo niekorzystny) i do wywołania drugiego ze zjawisk (stan najbardziej korzystny).

$\mathrm{Z}$ analizy literatury widać, że ujęcie tematu jest oryginalne, a uzyskane wyniki będą przypuszczalnie pierwszymi badaniami, w których $\mathrm{w}$ usystematyzowany i obszerny sposób podjęto wysiłek poznania, sklasyfikowania i określenia okoliczności występowania różnych zachowań dynamicznych pojazdów szynowych $\mathrm{W}$ KP podczas ruchu $\mathrm{Z}$ prędkościami wyższymi od krytycznej. Wydaje się, że powodzenie $\mathrm{w}$ realizacji celów zadania może $\mathrm{w}$ pewnym stopniu zmienić postrzeganie kolejowych krzywych przejściowych, tak przez środowisko zajmujące się dynamiką pojazdów jak i to zajmujące się budową dróg kolejowych. Osiągnięcie celów byłoby $\mathrm{z}$ pewnością ważnym i oczekiwanym uzupełnieniem bardzo skromnej wiedzy, dotyczącej dynamiki pojazdów szynowych w KP powyżej prędkości krytycznej. Prezentacja uzyskanych wyników przyczyni się zapewne do ożywienia zainteresowania tą tematyką na świecie.

Praca naukowa współfinansowana ze środków MNiSW na naukę w latach 2009-2012 jako projekt badawczy nr N N509 403136.

\section{Lit e r a tur a}

[1] Praca zbior. kier. Zboiński K., Komputerowe badania układu tor-pojazd szynowy na tuku kołowym i krzywej przejściowej. Raport końcowy Grant KBN nr 3054691 01, Wydziat Transportu PW, Warszawa 1994.

[2] Zboiński K., Dynamical investigation of railway vehicles on a curved track. European Journal of Mechanics, Part A Solids, 17(6), str. 1001-1020, 1998.

[3] Zboiński K., Metodyka modelowania dynamiki pojazdów szynowych $z$ uwzględnieniem zadanego ruchu unoszenia i jej zastosowania. Prace Naukowe PW - Transport, z. 43, Oficyna Wydawnicza PW, Warszawa 2000.

[4] Zboiński K, Dusza M., Symulacyjne badania dynamiki pojazdów szynowych $w$ torze zakrzywionym. XV Konferencja NaukowoTechniczna Pojazdy Szynowe, Prace Naukowe Instytutu Konstrukcji $i$ Eksploatacji Maszyn Politechniki Wroctawskiej, $\mathrm{Nr} 86$, Konferencje $\mathrm{Nr}$

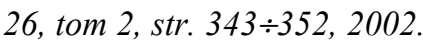

[5] Zboiński K., Selected problems of non-linear (nonsmooth) dynamics of rail vehicles in a curved track, str. 87-99. W pracy pod red.: Thomsen P.G., True H., Non-smooth problems in Vehicle Systems Dynamics, Springer-Verlag, Berlin, Heidelberg 2010.

[6] Hoffmann M.: Dynamics of European two-axle freight wagons. PhD thesis, Technical University of Denmark, Informatics and Mathematical Modelling, Lyngby, Denmark 2006.

[7] Zboiński K.: The importance of kinematics accuracy in modelling the dynamics of rail vehicle moving in a curved track with variable velocity. International Journal of Heavy Vehicle Systems, 18(4), str. 411446, 2011

[8] Zboiński K.: Modelling dynamics of certain class of discrete multi-body systems based on direct method of the dynamics of relative motion. Meccanica, 47(6), str. 1527-1551, 2012, Springer, DOI: 10.1007/s11012-011-9530-1.

[9] Zboiński K., Dusza M., Self-exciting vibrations and Hopf's bifurcation in non-linear stability analysis of rail vehicles in curved track, European Journal of Mechanics, Part A/Solids, 29(2), str. 190-203, 2010.

[10] Zboiński K., Dusza M., Extended study of rail vehicle lateral stability in a curved track, Vehicle System Dynamics, 49(5), str. 789-810, 2011.

[11] Zboiński K., Dusza M., A Simulation Study of the Track Gauge Influence on Railway Vehicle Stability in Curves", in J. Pombo, (Editor), "Proceedings of the First International Conference on Railway Technology: Research, Development and Maintenance", Civil-Comp Press, Stirlingshire, UK, Paper 67, 2012. doi:10.4203/ccp.98.67

[12] Zboiński K.: Numerical studies on railway vehicle response to transition curves with regard to their different shape. Archives of Civil Engineering, 44(2), str.151-181, 1998. 
[13]Zboiński K., Woźnica P.: Optimisation of the railway transition curves' shape with use of vehicle-track dynamical model. Archives of Transport, 22(3), str. 387-407, 2010.

[14]Zboiński K., Woźnica P., Optimisation of Railway Polynomial Transition Curves: A Method and Results", in J. Pombo, (Editor), "Proceedings of the First International Conference on Railway Technology: Research, Development and Maintenance", Civil-Comp Press, Stirlingshire, UK, Paper 60, 2012. doi:10.4203/ccp.98.60.

[15]Long X.Y., Wei Q.C., Zheng F.Y.: Dynamical analysis of railway transition curves. Proc. IMechE part $F$ Journal of Rail and Rapid Transit, 224(1), str. 1-14, 2010.
[16]Kalker J.J.: A fast algorithm for the simplified theory of rolling contact. Vehicle System Dynamics, 11, str. 1-13, 1982.

[17]Choromański W., Zboiński K., Pakiet softwarowy do automatycznej generacji równań ruchu $i$ analizy dynamiki pojazdu. Materiaty $X$ Konferencji Naukowej Pojazdy Szynowe, tom 3, str. 34-55, Politechnika Wrocławska, Wrocław 1994.

[18]Polach O., Characteristic parameters of nonlinear wheel/rail contact geometry. Proceedings of 21st IAVSD Symposium, Paper 95, str. 1-12, 17-21 Sierpnia 2009, KTH, Stockholm, Sweden. 